\title{
Improving student literacy in adult education through an immediate feedback tool
}

\author{
Martie Geertsema \\ School of Education \\ The University of Queensland \\ Brisbane, Australia \\ m.geertsema@uq.edu.au
}

\author{
Chris Campbell \\ School of Education \\ The University of Queensland \\ Brisbane, Australia \\ chris.campbell@uq.edu.au
}

\begin{abstract}
Intelligibility is what every English language learner strives for. To have the correct pronunciation and to be understood is a big part of the challenge to learning a new language. A contributing factor that makes correcting learner pronunciation difficult is the fact that many learners are unable to hear their own pronunciation mistakes, so speech to audio programs have limited value. A potential benefit of speech to text programs is that learners will be able to see their mistakes and thereby correct their own pronunciation with a technology they always have with them, is familiar with and is non-threatening. In addition, the fact that in remote areas $3 \mathrm{G}$ is more available than the Internet and mobile phones are cheaper than other digital literacy tools like iPads or laptops makes mobile phones as a teaching tool an appealing prospect. This project explores the possibilities DragonDictation, a free mobile phone app for voice recognition, brings to the adult ESL classroom, not only for the learners but also for the teachers. The extent to which it could be useful as an immediate feedback tool on pronunciation accuracy is explored, as are improvements to students speaking in English. The extent to which continued and supervised exposure to this digital literacy changes adult learners' beliefs on the place of using mobile phones as a teaching and learning tool is also explored.
\end{abstract}

\section{Author Keywords}

Mobile Learning, feedback, Apps, language learning, adult education

\section{INTRODUCTION}

Adult English language and literacy teaching practices are under scrutiny: with the boom in technology, the spread of English as an international language, and the fluidity of people and information, there have been calls for a re-evaluation and a renewal of current commonly accepted practices in class. 'Traditional methods' where learners unplug from their technology filled lives, sit in class and receive information have long been criticised. One possible suggestion to address this need for change is to investigate the effective use of mobile phones in class as a teaching and learning resource. As Auld, Snyder, and Henderson (2012) state: "New types of meaning-making practices can now be afforded through digital devices." (p. 282).

\section{LITERATURE REVIEW}

In an effort to make learning English easier for speakers of other languages, teachers try to apply and simulate real life situations to the classroom. Consequently, the place of digital literacy and the effective use of smart phones has become an emerging research area. Merchant (2012) advocates the importance of looking at the positive contributions mobile phones can make in a classroom and claims that the debate on whether to ban or allow phones in class is long outdated. Burnett and Merchant (2011) agree on the importance of teaching critical digital literacy and not simply the avoidance of digital literacy. Parry (2011) confirms that it is the teacher's responsibility to show learners how to "use these technologies effectively to ensure they end up on the right side of the digital divide: the side that knows how to use social media. .." (p. 2). Ng (2012) concurs and makes the case that teaching learners how to critically use technology is vital. She warns of the dangers of using technology in class as a babysitting tool, and points out that in order for technology to be effective, there needs to be an educational purpose.

Mobile phones can be used to improve the literacy of students with low literacy levels, as suggested by Namibia, Semali and Asino (2012). Auld et al. (2012) add to the research done in their study that focused on learners in remote Australia. In terms of digital literacy they caution for the need to see mobile phone usage within its cultural context of everyday usage and the need of the teacher to be culturally sensitive in acknowledging everyday practices within the learners' culture. They argue however, that mobile phones in the classroom can be an effective tool to bridge the perceived divide between home life and educational life. Gee (2010) concurs, and makes the case that print-based literacy is very similar to digital literacy, because both literacies demand that the learner find "ways of acting, interacting, valuing, believing, and knowing', which stem from their social situation." (p. 32).

The socio-cultural place of mobile phone usage not only as a digital literacy tool but also as a critical literacy device is strongly addressed in current literature on using mobile phone technology in the classroom. Potentially, it can be used 
effectively even in remote areas where other technologies and educational resources are unavailable. Moreover, the fact that mobile phones are so versatile, omnipresent and comparatively cheap, adds to its appeal as a teaching tool in class.

\section{THE RESEARCH PROBLEM}

English Language Teaching (ELT) has taken on this challenge for renewal. The new priority is now to help learners move away from sounding like a 'native speaker' to rather being internationally intelligible as a speaker of English (Cook 2007). This is mostly due to two reasons: firstly, the influences of globalisation and secondly, due to the large numbers of English language learners in the world. Pennington \& Hoekje (2010) indicate that in 2010 around 400 million people spoke English and its variations as a first language, 430 million spoke it in addition to their home language, and another 1 billion people were estimated to be learning English. One natural result of this is that 'Standard English' has become hard to define and subsequently, difficult to teach. A very real teaching implication is therefore that teachers need to accept a much wider range of pronunciation forms and variations as standard. For example, on teacher training courses like the CELTA, teachers are now taught only to correct learners' pronunciation when it interferes with meaning and understanding. This is however, much harder to do than it sounds. Intelligibility is linked to context and if the context were clear enough, would incorrect pronunciation lead to communication breakdown? Could the listener not infer what the speaker meant? Should there be that much focus on individual sounds? For example: in a discussion about a professional development workshop scheduled for today, a Chinese speaker of English makes a typical mistake with /1/ and $/ \mathrm{r} /$ and says:

"Let's just meet at the loom* downstairs at two." (*room)

To what extent should learners be taught to fight typical mispronunciation patterns that emerge from their first language? What is the difference between wrong pronunciation and it not being right?

In this global world, the ability to communicate effectively in English has become a priority not only for learners of English to improve their chances of securing employment, but also for the policy makers in non-English speaking countries (Guo, Guo, Beckett, Li, \& Guo, 2013). The Chinese government has made drastic education policy changes since 2001 and have been investing in their pre and in-service teachers' education to be able to implement these changes, sending them abroad for short intensive courses on current English language teaching pedagogy and methodology. Therefore, China and South-East Asia currently hold the biggest emerging language market, making English language learning a profitable international business.

There are a variety of teaching tools in use to help foster increased intelligibility in spoken English. One popular computer program in helping learners create meaning is Audacity, with which learners can listen to a model sample and record their own voices, play it back and analyse and compare their own samples with the model. Individual feedback from the teacher however, is time consuming and often open to the teacher's skill and interpretation. With the free mobile phone voice recognition application DragonDictation, speech is turned into text thereby making it possible for learners to compare the original written text with the transcription on their phones. The potential benefits are that this app might firstly help to raise linguistic and phonetic awareness in case learners could not hear their own mistakes. Secondly, it underscores the commonly held belief in ELT that many learners learn better when supported with visual links. And finally, it might function as an immediate, objective, individualised feedback tool for each learner. DragonDictation has the added advantage that learners can email their transcribed samples to themselves or the teacher for future reference and record keeping.

The ubiquitous nature of mobile phones makes it an appealing teaching resource in language classrooms. Moreover, it could potentially be highly instrumental in increasing digital literacy in adult learners.

\section{METHODOLOGY}

This study uses the exploratory sequential design in which to explore a phenomenon. The rationale behind using a mixed method design is that by using them together, they offer a clearer understanding of the phenomenon under investigation, than they can offer separately (Creswell 2012). Qualitative data from observations and focus group discussions will be used to determine how participants feel and what they believe about using mobile phones as an immediate feedback tool in an English language class. Next, quantitative data will be collected with the help of a survey to try and explain the relationships identified in the first stage of the study. This will be conducted in class as a paper survey. There will also be a pre and a post-test to establish a measure of effectiveness of the treatment.

The advantages to following the exploratory sequential design are primarily two tiered: firstly, the data acquired from participants are used to identify measures. Secondly, by first collecting qualitative data, the researcher can be more openminded about the phenomenon under investigation because the focus of the study is not to try and confirm pre-conceived ideas or already decided variables, but to explore a phenomenon.

In this study there are three research questions:

1. What are the perceived barriers of learners in using mobile phones as a learning tool in English language classes? 
2. To what extent does increased exposure to a digital literacy add to learner confidence and pronunciation accuracy when learners use mobile phones as an immediate feedback tool in class?

3. To what extent is DragonDictation a suitable teaching tool in English language classes?

Data was collected from eight students who attended an English Language course in Brisbane, Australia. They attended this course from July to August, 2013 and were placed in a class for learners progressing from a B2-C1 level according to the Common European Framework. As there was a constant influx and turnover of students only those who could be tested both on the first day and on the last day have been used for the results section. Students included four male and four female students aged 19 to 39. In total, 10 school lessons (roughly 10 hours over 3 weeks) were spent practicing with the app. Ethics approval for the project was obtained prior to the data collection and as such names have been changed in the results section.

There was a control group from one of the other classes at the same Language Centre in Brisbane, Australia. This class had students learning at the same level of English as the study group and included a total of six students, with one male student and five female students in the group. The control group did the pre and post-test only and did not use DragonDictation in class at any other time during the course of the study. However, after the end of the study some professional development training by the researcher has been planned and the other teachers will learn how to use DragonDictation so that the control group (and other classes) can use the app to improve their speaking.

\section{RESULTS AND DISCUSSION}

Initially the students were asked to do a pre-test. This involved first checking the students understood the meaning of the words and the text as a whole, after which the students read a paragraph, (Aesop's Fable, The Dog and the Shadow) into the DragonDictation app. The file transcript and the audio file were then emailed to the teacher and a record kept. Results are still being analysed in full and this paper presents an initial analysis.

The class was then taught for ten lessons with each lesson having a different phonological focus. Interestingly after the pre-test, students from various countries had the same type of errors which can be seen in Table 1 .

\begin{tabular}{|c|c|c|c|}
\hline Name & Country & Learner Errors & List of common errors \\
\hline $\begin{array}{l}\text { Anita } \\
\text { Nelly }\end{array}$ & Taiwan & 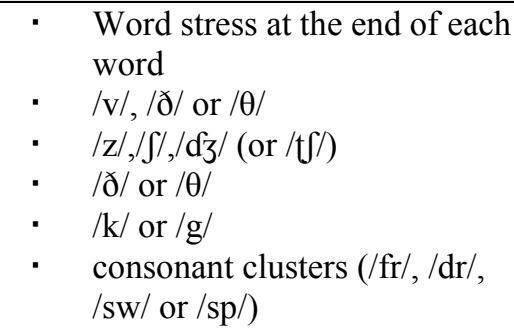 & \multirow[t]{5}{*}{$\begin{array}{ll}\cdot & / \mathrm{s} / \text { or } / \mathrm{z} / \\
\cdot & / \mathrm{d} / \text { or } / \theta / \\
\cdot & \text { linking with } / \mathrm{n} /, / \mathrm{j} /, / \mathrm{r} / \\
& \text { or } / \mathrm{w} / \text { in connected } \\
& \text { speech } \\
\cdot & \text { diphthongs }\end{array}$} \\
\hline Sally & Japan & $\begin{array}{ll}\cdot & / 1 / \text { or } / \mathrm{r} / \\
\cdot & / \mathrm{z} / / \mathrm{d} / / \mathrm{d} \mathrm{d} / \text { or } / \mathrm{s} / \\
\cdot & / \mathrm{v} / \text { or } / \mathrm{b} / \\
\cdot & / \mathrm{t} /, / \mathrm{d} / \\
\cdot & \text { consonant clusters }\end{array}$ & \\
\hline Victoria & Chile & \multirow{2}{*}{$\begin{array}{ll}\cdot & / \mathrm{v} /, / \mathrm{w} /, / \mathrm{b} / \text { or } / \mathrm{d} / \\
\cdot & / \mathrm{z} / / \mathrm{s} /, / \mathrm{g} / \text { or } / \mathrm{d} \zeta / \\
\cdot & / \mathrm{j} / \text { or } / \mathrm{d} / / \\
\cdot & \text { over- or underuse of } / \mathrm{a} / \\
\cdot & \text { consonant clusters }\end{array}$} & \\
\hline Steve & Brazil & & \\
\hline $\begin{array}{l}\text { Mustafa } \\
\text { Sami } \\
\text { Hamdi }\end{array}$ & Saudi Arabia & $\begin{array}{ll}\cdot & \text { consonant clusters } / \mathrm{pl} / \text { or } / \mathrm{pr} / \text {, } \\
\text { /sp/, } / \mathrm{skr} /, \mathrm{spl} / \\
\cdot \quad / \mathrm{d} / \text { or } / \mathrm{t} / \\
\cdot & / \mathrm{p} / \text { or } / \mathrm{b} / \\
\cdot & / \mathrm{v} / \text { or } / \mathrm{f} / \\
\cdot & / \mathrm{s} / \text { or } / \mathrm{z} / \\
\cdot & \text { shortened diphthongs } \\
\end{array}$ & \\
\hline
\end{tabular}

Table 1: A list of common errors from the students recorded during the pre-test.

As can be seen in Table 2 the treatment was quite extensive for each of the ten lessons. The students were taught over a period of three weeks with each lesson lasting approximately one hour and with each one focused on a different type of phonological area. 


\begin{tabular}{|c|c|c|}
\hline Day & Area & Example \\
\hline 1 & $/ \mathrm{s} /$ or $/ \mathrm{z} /$ & $\begin{array}{l}\text { Sounds in the beginning, middle and end positions, as well as in sentences } \\
\text { For example: soap, assume, miss / zip, buzzer, nose } \\
\text { The boss is always out }\end{array}$ \\
\hline 2 & $/ ð /$ or $/ \theta /$ & $\begin{array}{l}\text { Sounds in the beginning, middle and end positions, as well as in sentences } \\
\text { For example: thing, toothbrush, with / that, wither, smooth } \\
\text { I can't go with Alan }\end{array}$ \\
\hline 3 & $\begin{array}{l}\begin{array}{l}\text { Connected speech } \\
\text { between two vowels }\end{array} \\
\text { with } / \mathrm{w} / \\
\end{array}$ & Two apples - to wapples/ Do I have to do every question? \\
\hline 4 & Tongue twisters & $\begin{array}{l}\text { A proper copper coffee pot } \\
\text { Red leather, yellow leather, read leather, red leather } \\
\text { Long legged ladies last longer }\end{array}$ \\
\hline 5 & Linking $/ \mathrm{n} /, \mathrm{j} /$ or $/ \mathrm{r} /$ & $\begin{array}{l}\text { I expect you know Ian Green? } \\
\text { Why, I wonder? Is he influential? } \\
\text { Mummy always knows best. }\end{array}$ \\
\hline 6 & Front vowels & $\begin{array}{l}\text { meet, mit, met, mat, mutt } \\
\text { Pete, pit, pet, pat, putt } \\
\text { bean, bin, Ben, ban, bun }\end{array}$ \\
\hline 7 & $\begin{array}{l}/ \mathrm{d} 3 / \text { or } / \mathrm{t} / \\
/ \mathrm{b} / \text { or } / \mathrm{v} /\end{array}$ & $\begin{array}{l}\text { George, it's not possible! You can't judge a beauty contest! } \\
\text { bet - vet, boat - vote } \\
\text { This van is going very fast } \\
\text { The bus was very full containing } / \theta / / \mathrm{b} / / \mathrm{w} / \text { and } / \mathrm{z} /, / \mathrm{v} / / \mathrm{f} /\end{array}$ \\
\hline 8 & Word and sentence stress & $\begin{array}{l}\text { Can I have a coffee and a pot of tea, please? } \\
\text { Would you like another one? } \\
\text { Thanks for a lovely meal. }\end{array}$ \\
\hline 9 & $\begin{array}{l}\text { Long vowels vs. short vowels, } \\
\text { sliding diphthongs }\end{array}$ & $\begin{array}{l}\text { service - surface/ prove - proof } \\
\text { heard, hurt, heart } \\
\text { sheer, share, sure } \\
\text { peer, pair, pure } \\
\text { How dare you disobey me? } \\
\text { What about giving me my share? }\end{array}$ \\
\hline 10 & $\begin{array}{l}\text { Clusters with } / \mathrm{tr} /, / \mathrm{dr} / \text { or } / \mathrm{tw} / \text {, } \\
/ \mathrm{kl} /, / \mathrm{gl} /, / \mathrm{kr} /, / \mathrm{gr} / \text { or } / \mathrm{kr} /\end{array}$ & $\begin{array}{l}\text { A: How are you travelling, Trevor? } \\
\text { B: By train. The twelve twenty } \\
\text { A: Shall I drive you to the station? } \\
\text { A: You're back quickly. Didn't you go to the cricket club? Was it crowded? } \\
\text { B: I went. It was quite crowded and Greg was there too. }\end{array}$ \\
\hline
\end{tabular}

Table 2: The activities each day that focused on various types of speech. 
During the lessons the activities were taken from Hooke and Rowell (1982) as well as from Mortimer (1994). The class also used various types of tongue twisters from this website: www.englishclub.com/pronunciation/tongue-twisters.htm. Another website showed learners how sounds can be formed $\mathrm{http}: / / \mathrm{www}$.uiowa.edu/ acadtech/phonetics/\#. This was a visual reminder to the students who really liked to be able to see what part of the mouth needed to move, for example, the tongue moves to the top of the mouth when some sounds are made and the bottom of the mouth when others are made. One observation made in class was that by the end of the study students were actually correcting each other with this while in class and not when using the app, but at other times.

\begin{tabular}{|c|c|c|c|}
\hline Learner & Sample & Pre-test & Post-test \\
\hline $\begin{array}{l}\text { Sally } \\
\text { (Japan) }\end{array}$ & $\begin{array}{l}\text { The dog and the shadow: } \\
\text { It happened that a dog had got a } \\
\text { piece of meat and was carrying it } \\
\text { home in his mouth to eat it in } \\
\text { peace. Now on his way home he } \\
\text { had to cross a plank lying across } \\
\text { a running brook. As he crossed, } \\
\text { he looked down and saw his own } \\
\text { shadow reflected in the water } \\
\text { beneath. Thinking it was another } \\
\text { dog with another piece of meat, } \\
\text { he made up his mind to have that } \\
\text { also. So he made a snap at the } \\
\text { shadow in the water, but as he } \\
\text { opened his mouth the piece of } \\
\text { meat fell out, dropped into the } \\
\text { water and was never seen more. }\end{array}$ & $\begin{array}{l}\text {.doc on the shovel } \\
\text { it happen... Cahaba Glotfelty } \\
\text { assailed me on my scatting it } \\
\text { Kukhwan in his Mosside to eat it } \\
\text { in peace not all his way home he } \\
\text { Hototo costs upon crying a call } \\
\text { sidelining Breuk as he crossed } \\
\text { David down on saltiest } \\
\text { Longshadow if it did Ingala } \\
\text { beanies thinking it Clasara Dock } \\
\text { this RFLPs centimeter she made } \\
\text { up his mind to habitat also } \\
\text { sashimi adopts not at the shadow } \\
\text { in the Waka back as he opened his } \\
\text { mosque episode Maidenfair out } \\
\text { talked into the Wallpack on last } \\
\text { Nablus Simoron }\end{array}$ & $\begin{array}{l}\text { It happened... Have you got that } \\
\text { piece of meat and was carrying it } \\
\text { time... Must do it it in peace now } \\
\text { on his way home he had the } \\
\text { Killcross apparent lying across } \\
\text { the Luning broke as he crossed } \\
\text { you get down and saw his shadow } \\
\text { effective in the water Beneze } \\
\text { thinking it that another dog with } \\
\text { another piece of meat Humana up } \\
\text { his mind to happen.also saw him } \\
\text { at the snap at the shadow in the } \\
\text { water but I'll keep up on his mask } \\
\text { that piece of meat fell apart } \\
\text { stopped into the water and life } \\
\text { never seen more }\end{array}$ \\
\hline $\begin{array}{l}\text { Sami } \\
\text { (Saudi) }\end{array}$ & $\begin{array}{l}\text { The dog and the shadow: } \\
\text { It happened that a dog had got a } \\
\text { piece of meat and was carrying it } \\
\text { home in his mouth to eat it in } \\
\text { peace. Now on his way home he } \\
\text { had to cross a plank lying across } \\
\text { a running brook. As he crossed, } \\
\text { he looked down and saw his own } \\
\text { shadow reflected in the water } \\
\text { beneath. Thinking it was another } \\
\text { dog with another piece of meat, } \\
\text { he made up his mind to have that } \\
\text { also. So he made a snap at the } \\
\text { shadow in the water, but as he } \\
\text { opened his mouth the piece of } \\
\text { meat fell out, dropped into the } \\
\text { water and was never seen more. }\end{array}$ & $\begin{array}{l}\text { The dog got Dechado it's } 11 \text { that's } \\
\text { a dog how to go to the base of me } \\
\text { and was getting gets home and his } \\
\text { malls to eat in peace now on his } \\
\text { way home he had to go subglottic } \\
\text { laying across running dog eyes } \\
\text { Hiko said he looked down and so } \\
\text { is on Chouteau inflicted in the } \\
\text { water been syncing it tomorrow is } \\
\text { another dog with another base of } \\
\text { me he made up his mind to } \\
\text { house.also so he has made a snap } \\
\text { of the shadow in the water bath } \\
\text { soon as he opens his mouth piece } \\
\text { of me still out drop it into the } \\
\text { water and was never seen more }\end{array}$ & $\begin{array}{l}\text { It's how did the adult how to go to } \\
\text { a piece of meat and was carrying } \\
\text { gets home in his mouth to eat it in } \\
\text { the peace know on his way home } \\
\text { he had to cross a Blahnik blank } \\
\text { across is a running book's Hiko } \\
\text { said he locked down on so his } \\
\text { own shadow reflected in the } \\
\text { water beings sinking in its was } \\
\text { another dog with another piece of } \\
\text { meat he made up his mind to } \\
\text { house that also so he made us the } \\
\text { shadow in the water books is he } \\
\text { old and his mouth the base of me } \\
\text { feel out drop into the the water }\end{array}$ \\
\hline
\end{tabular}

Table 3: Two examples of student's results with the text on the left side and the pre and post-test results

As can be seen from Table 3 the two students improved greatly throughout the period of practice. Practice was completed in class with the most common mistakes being focused on. This did not include the focusing on vowel sounds as these sounds are where accents occur and because English as an International Language is being taught, the learners' choice of accent was respected.

The control group performed much the same in the pre and the post-test as can be seen from the two examples given in Table 4. Thus, it is shown that the study group was effective with the lessons using the app, although greater analysis would be beneficial (and will occur in the future). 


\begin{tabular}{|c|c|c|c|}
\hline Name & Master Copy & Pre-test & Post-test \\
\hline Rag & $\begin{array}{l}\text { The dog and the shadow: } \\
\text { It happened that a dog had got a } \\
\text { piece of meat and was carrying it } \\
\text { home in his mouth to eat it in } \\
\text { peace. Now on his way home he } \\
\text { had to cross a plank lying across } \\
\text { a running brook. As he crossed, } \\
\text { he looked down and saw his own } \\
\text { shadow reflected in the water } \\
\text { beneath. Thinking it was another } \\
\text { dog with another piece of meat, } \\
\text { he made up his mind to have that } \\
\text { also. So he made a snap at the } \\
\text { shadow in the water, but as he } \\
\text { opened his mouth the piece of } \\
\text { meat fell out, dropped into the } \\
\text { water and was never seen more. }\end{array}$ & $\begin{array}{l}\text { It happened that dog had got a } \\
\text { piece of meat and was caring it } \\
\text { home in his mouth to eat it in } \\
\text { peace now on his way home he } \\
\text { had to cross a blank lying across a } \\
\text { running broke as he as he crossed } \\
\text { he he looked down and saw his } \\
\text { own shadow reflected in the water } \\
\text { beneath thinking it was another } \\
\text { dog with another piece of meat he } \\
\text { made up his mind to have that } \\
\text { also so he made a snap at the } \\
\text { shadow in girl water back OCR } \\
\text { and his mouth a piece of meat so } \\
\text { I'll drop into the water and was } \\
\text { never seen more }\end{array}$ & $\begin{array}{l}\text { The dog and the shadow talking } \\
\text { that a dog had called a piece of } \\
\text { meat and laws can we make it } \\
\text { home in his mouth to eat it and } \\
\text { peace know when his way home he } \\
\text { had to cross the line lying across } \\
\text { Iraq I'm running out as he crossed } \\
\text { he looked down and so he's on } \\
\text { shadow reflected in the water } \\
\text { beneath thinking it was another dog } \\
\text { with another piece ofmeat he made } \\
\text { up his mind to have that also so he } \\
\text { made a snap at the shadow in the } \\
\text { water but as he often his mom the } \\
\text { piece of meat fill out drop into } \\
\text { without water and was never seen } \\
\text { more }\end{array}$ \\
\hline Louisa & $\begin{array}{l}\text { The dog and the shadow: } \\
\text { It happened that a dog had got a } \\
\text { piece of meat and was carrying it } \\
\text { home in his mouth to eat it in } \\
\text { peace. Now on his way home he } \\
\text { had to cross a plank lying across } \\
\text { a running brook. As he crossed, } \\
\text { he looked down and saw his own } \\
\text { shadow reflected in the water } \\
\text { beneath. Thinking it was another } \\
\text { dog with another piece of meat, } \\
\text { he made up his mind to have that } \\
\text { also. So he made a snap at the } \\
\text { shadow in the water, but as he } \\
\text { opened his mouth the piece of } \\
\text { meat fell out, dropped into the } \\
\text { water and was never seen more. }\end{array}$ & $\begin{array}{l}\text { it happening about GOT a piece } \\
\text { of meat and was carrying it home } \\
\text { in his mile to hit in peace now on } \\
\text { his way home he had to cross up } \\
\text { Langlais in the Christmas } \\
\text { morning's ASCII crusted he'll get } \\
\text { down and saw his away shadow } \\
\text { reflected in the wider than you } \\
\text { think it was another dog with } \\
\text { another piece of meat she needs } \\
\text { up his mind to heart that always } \\
\text { so she may does now at the } \\
\text { Shaddle in the wider that ask your } \\
\text { Bennett's is miles the piece of } \\
\text { meat feel out drop it in the bit } \\
\text { worried I was never seen more } \\
\text { moderate of us and they but be } \\
\text { careful not to be lost what you } \\
\text { half because you're reaching at } \\
\text { chapel }\end{array}$ & $\begin{array}{l}\text { Back up on the Schappet is helping } \\
\text { it doesn't sell CUTCO taffies of me } \\
\text { I was carrying in Haninch } \\
\text { Eastmount eat increased now he's } \\
\text { way home he trekked across upland } \\
\text { Diana Crescentlane Innsbruk as he } \\
\text { cresset Setucket down on so he's I } \\
\text { went shadowgraph dictating to one } \\
\text { of any thinking he was NRA.with } \\
\text { another piece of meat she made-up } \\
\text { she's mine don't have to Dutchboy } \\
\text { soon so he Mayvis not a } \\
\text { Bayshadow Rionda Wyanet but ask } \\
\text { you eponyms she's mahlstick piece } \\
\text { of me fanout drop it into the water } \\
\text { I was never Seymour Marnae of a } \\
\text { soap favorite because Sweetmilk } \\
\text { Tallulas why do hot because you } \\
\text { are preaching upchucks }\end{array}$ \\
\hline
\end{tabular}

Table 4: Two examples of the control group pre and post-test results.

The three research questions have been briefly answered in this section.

Research Question 1: What are the perceived barriers of learners in using mobile phones as a learning tool in English language classes?

In the focus group discussions, almost all the participants expressed their belief and concerns about using mobile phones as a learning tool in class. Their reasons varied from the fact that it is a distraction to suggesting that social media and IM would make it hard for them to focus on the lesson. Some students also felt that their social life should stay outside the class because a classroom is for learning, and that using dictionaries in paper format has been good enough for years when they were at school, it could be useful now too.

In the post study survey almost all the participants had changed their minds in this regard by reporting that mobile phones are useful in learning English and that they would recommend DragonDictation to their friends. This is a positive change in their attitudes and suggests that the students worked through the barriers that may have limited their learning if they had not changed their attitude. 
Research Question 2: To what extent does increased exposure to a digital literacy add to learner confidence and pronunciation accuracy when learners use mobile phones as an immediate feedback tool in class?

The learners were observed as becoming increasingly more confident as they used the app and saw their immediate, personalised results. On day 0, learners said "This app is broken!" and one threw the phone across the table; on day 4 while reading a text on the benefits of chewing gum, the teacher pointed out the meaning difference in 'shoe' and 'chew' when learners mispronounced it. Learners then autonomously produced their phones, started dictating 'shoe/chew' into their phones to check their own pronunciation and persisted until they got it right; on day 6 learners self-identified that /b/ and $/ \mathrm{v} /$ were an area they need to address, and asked for help. On day 7 learners independently started peer correcting each other by showing the correct mouth movements to make certain sounds and on day 9 learners said: "We are ready. Test us tomorrow!"

As can be seen from the samples of the treatment group, even before statistical analysis the improved results on learner accuracy are clearly visible.

\section{Research Question 3: To what extent is DragonDictation a suitable teaching tool in English language classes?}

There is clear evidence from the pre and post-tests, the observations and post survey that DragonDictation is a very useful teaching tool, when used regularly in a focused manner as a learning tool in class. The fact that it works only on iPhones was problematic, and the fact that it only registers three different varieties of English (albeit seemingly the most sought after pronunciation variation for learners) might be something the creators would like to reconsider in the future.

\section{LIMITATIONS OF THE STUDY}

There are some limitations to this project with those being the type of phone, the small sample size and other limitations such as the size of the group. The main limitation is that the app worked only on iPhones. Consequently, learners with Androids were sharing phones so that everyone could get some practice in class. This resulted in much more time than anticipated spent on the project in class. Each day roughly an hour was spent, whereas the expectation was that it would be around 20 minutes. The fact that learners were sharing phones, might also account for the fact that some students (iPhone owners) performed so much better in the post-test than other students (Android owners).

It was a small sample over a short period of time with only eight students (four male and four female, aged 19 to 39 ) participating in both the pre and the post-tests. In total, only 10 school days (roughly 10 hours over 3 weeks) were spent practicing with the app. Although the app caters for the biggest variety of English on the market (US/ UK/ Aus), it does not accommodate speakers of World Englishes, or even other English accents which means that students need to choose the type of English they are more closely aligned with. DragonDictation does not register intonation, which is an important feature for learners of English to practice.

One final limitation is the treatment group consisted of eight participants, from five different countries. The treatment consequently prioritised common errors as much as possible, but in a homogenous, mono-lingual group the practice activities might be more applicable to everyone.

\section{CONCLUSIONS}

When it comes to keeping up to date with emerging pedagogies and teaching approaches, the effective use of mobile phones as a learning and teaching resource deserves more attention. In helping learners on their quest to create meaning, improve their intelligibility and increase their autonomy as English learners and competent speakers, mobile phone technology may be indispensable in the future. This would be a practical example of bringing real life into the classroom, making learning concrete and practical thereby preparing learners for real life situations, using real language.

In the future a follow on study might be to investigate how and where students are practicing their pronunciation using the app DragonDication. This would follow on very nicely from this initial study with a small number of students that only investigated students in class use of the app.

Voice recognition software as an immediate feedback tool on a smart phone will certainly have a place in future classrooms. Not only are mobile phones readily available, they are relatively cheap, easy to operate, innocuous and there are copious amounts of phone apps available for free download to make life easier.

\section{ACKNOWLEDGEMENTS}

The authors would like to acknowledge the Navitas English Language Centre in Brisbane for allowing this project to be conducted. A special thanks to the Director of Studies, Louise Kane for being so positive about this project. This project was conducted as part of a Masters course at The University of Queensland.

\section{REFERENCES}

Auld, G., Snyder, I., \& Henderson, M. (2012). Using mobile phones as placed resources for literacy learning in a remote Indigenous community in Australia. Language and Education, 26(4), 279-296. doi.org/10.1080/09500782.2012.691512 
Burnett, C. \& Merchant, G. (2011). Is there a space for critical literacy in the context of new media? English, Practice and Critique, 10(1), 41-57.

-Coleman, E.G. (2010). Ethnographic Approaches to Digital Media. Annual Review of Anthropology, 39, 487-505. doi: 10.1146/annurev.anthro.012809.104945

Cook, V. (2007). The goals of ELT: Reproducing native-speakers or promoting multicompetence among second language users? In J. Cummins and C. Davison (Eds.) International Handbook of English Language Teaching. (pp 237-248). New York: Springer.

Creswell, J.W. (2012). Educational Research: planning, conducting, and evaluating quantitative and qualitative research (Fourth Edition). Boston: Pearson.

Gee, J.P. (2010). New digital media and learning as an emerging area and "worked examples" as one way forward. Cambridge, MA: MIT Press.

-Guo, S., Guo, Y., Beckett, G., Li, Q., \& Guo, L. (2013). Changes in Chinese education under globalisation and market economy: emerging issues and debates. Compare: A Journal of Comparative and International Education, 43(2), 244264. doi.org/10.1080/03057925.2012.721524

Hooke, R. \& Rowell, J. (1982). A Handbook of English Pronunciation. London: Edward Arnold

- Merchant, G. (2012). Mobile practices in everyday life: Popular digital technologies and schooling revisited. British Journal of Educational Technology 43(5), 770-782. doi:10.1111/j.1467-8535.2012.01352.x

Mortimer, C. (1994). Elements of Pronunciation. Cambridge: Cambridge University Press.

-Ng, W. (2012). Can we teach digital natives digital literacy? Computers \& Education, 59, 1065-1078.

Parry, D. (2011). Mobile perspectives: on teaching mobile literacy. Educause Review. Retrieved from http://net.educause.edu/ir/library/pdf/ERM1120.pdf (pp. 1-3).

Pennington, M. C., \& Hoekje, B.J. (2010). Chapter one the language program in a changing world. In M.C. Pennington, \& B.J. Hoekje (Eds.) Language program leadership in a changing world: An ecological model (Innovation and Leadership in English Language Teaching, Volume 1), (pp. 3-18). Emerald Group Publishing Limited.

Semali, L.M. \& Asino, T.I. (2012). Postliteracy in the digital age: The use of mobile phones to support literacy practices in Namibia and Tanzania. Prospects, DOI 10.1007/s11125-012-9254-6

Swan, M. \& Smith, B. (1999). Learner English: A teacher's guide to interference and other problems. Cambridge University Press. 
This article has been cited by:

1. Chris Campbell, Martie Geertsema 40, 541. [CrossRef] 